\title{
Dzieje Instytutu Języka Polskiego im. Ireny Bajerowej
}

The History of the Irena Bajerowa Institute of the Polish Language

Słowa klucze: Instytut Języka Polskiego, Uniwersytet Śląski, historia

Key words: Institute of the Polish Language, University of Silesia, history

Niedawno Instytut Języka Polskiego Uniwersytetu Śląskiego w Katowicach obchodził jubileusz czterdziestolecia swojego istnienia. Ponieważ w związku z restrukturyzacją Uniwersytetu Śląskiego ta ważna jednostka Wydziału Filologicznego przestaje istnieć, warto przypomnieć jej historię, a przede wszystkim osoby, które ją tworzyły i nadały kształt badawczy katowickiemu językoznawstwu polonistycznemu.

Środowisko to zaczęło się kształtować jeszcze przed powstaniem Uniwersytetu Śląskiego, kiedy w Katowicach działała Wyższa Szkoła Pedagogiczna. To w murach tej uczelni na Wydziale Filologiczno-Historycznym została w roku 1953 powołana Katedra Języka Polskiego, kierowana najpierw przez Janinę Żlabową (1953-1961), a następnie przez Stanisława Jodłowskiego (1961-1965). Od początku Katedra była wspierana - zarówno dydaktycznie, jak i naukowo - przez pracowników przyjeżdżających z Krakowa. Zajęcia na katowickiej polonistyce prowadzili wówczas młodzi doktorzy z Uniwersytetu Jagiellońskiego: Witold Mańczak, Maria Honowska, Irena Bajerowa, Kazimierz Polański oraz - jeszcze jako magister - Walery Pisarek. Z tego grona na stałe ze śląską uczelnią związali się Irena Bajerowa oraz Kazimierz Polański. Kiedy popatrzymy z dzisiejszej perspektywy na dalsze losy wszystkich wymienionych lingwistów krakowskich, to docenić musimy, jak solidne fundamenty naukowe otrzymała nowo utworzona w Katowicach Katedra Języka Polskiego.

Od początku swojego istnienia Katedra łączyła działalność dydaktyczną z misją naukową wobec środowiska śląskich studentów, dlatego też od razu powołano Koło Naukowe Językoznawców, którym kierował najpierw Witold Mańczak, później Zbigniew Gołąb, a następnie Irena Bajerowa. Swoją obecność w Kole zaznaczył także Walery Pisarek - pierwszy doktorant w katowickiej Katedrze Języka Polskiego; jego rozprawa Nagłówek wypowiedzi prasowej $w$ oświetleniu lingwistycznym była też pierwszym doktoratem obronionym $w$ tej Katedrze (w 1966 r.; por. też PISAReK, 1967).

Działalność naukowa pracowników Katedry początkowo koncentrowała się głównie na kwestiach poprawności językowej oraz na problemach języka polskiego na Śląsku, co wynikało z usytuowania tej jednostki $w$ regionie o wyraźnie zaznaczonej specyfice tożsamoś-

\footnotetext{
* e-mail: miroslawa.siuciak@us.edu.pl
} 
ciowej i językowej. Z tego powodu rozpoczęto badania zmierzające do opracowania historii języka polskiego na Górnym Śląsku (nieznanej wówczas, ponieważ wszystkie powstałe po II wojnie światowej historycznojęzykowe prace śląskoznawcze ogniskowały się wokół dziejów Dolnego Śląska). Prekursorką tego nurtu stała się Alina Kowalska, której pierwsze zadanie badawcze - odnalezienie materiałów językowych w licznych archiwach województwa śląskiego - zaowocowało później wieloma publikacjami, ukazującymi się w ciągu jej ponad czterdziestoletniej działalności naukowej. Chciano się też przyjrzeć aktualnej sytuacji językowej na Górnym Śląsku. W tym celu został powołany Zakład Dialektologii Śląskiej, którym od roku 1960 kierował dialektolog z Krakowa - Alfred Zaręba, pełniący jednocześnie funkcję kierownika Pracowni Atlasu Gwar Śląskich Śląskiego Instytutu Naukowego $w$ Katowicach. Efektem wieloletniej działalności tego badacza są Śląskie teksty gwarowe (ZARÉBA, red., 1961) oraz Atlas językowy Śląska (ZARÉBA, 1969-1989).

W styczniu 1965 roku kierownikiem Katedry Języka Polskiego została Irena Bajerowa, która rok wcześniej uzyskała habilitację na podstawie rozprawy Kształtowanie się systemu polskiego języka literackiego $w$ XVIII wieku (BAjerowA, 1964). Ta przełomowa praca na długo zdeterminowała metody analizy i interpretacji procesu historycznojęzykowego, a niezwykła osobowość uczonej wpłynęła na profil naukowy Katedry. Jako jednostka naukowa i dydaktyczna Katedra łączyła jednak dwa nurty myślenia o języku: diachroniczny oraz synchroniczny. Badania nad polszczyzną współczesną skoncentrowane były na opisie systemu słowotwórczego i składniowego. Z inspiracji Kazimierza Polańskiego, pod organizacyjnym kierownictwem Henryka Wróbla zaczęto wówczas zbierać materiały do słownika generatywnego czasowników polskich. Prace trwały kilkanaście lat i zostały zwieńczone wydaniem pięciotomowego Słownika syntaktyczno-generatywnego czasowników polskich (Polański, red., 1980-1992).

W czerwcu 1968 roku katowicka WSP została przekształcona w Uniwersytet Śląski, co spowodowało wiele istotnych zmian organizacyjnych. Cztery dotychczas działające katedry o profilu polonistycznym, tzn. Katedra Języka Polskiego, Katedra Literatury Polskiej, Katedra Literatury Powszechnej oraz Katedra Metodyki Nauczania Historii Literatury i Języka Polskiego, utworzyły Instytut Filologii Polskiej, w którym Irena Bajerowa pełniła funkcję wicedyrektora, a dyrektorem był historyk literatury staropolskiej Jan Kazimierz Zaremba. W ramach Instytutu Filologii Polskiej działał kierowany przez Bajerową Zakład Języka Polskiego.

Przełomowy dla rozwoju filologii na Uniwersytecie Śląskim okazał się rok 1973, kiedy misję zorganizowania Wydziału Filologicznego w Sosnowcu powierzono Władysławowi Lubasiowi. To $w$ tym czasie obok istniejącej już polonistyki powstało na Uczelni prężnie działające środowisko neofilologów, zasilone młodymi badaczami z różnych polskich uniwersytetów. Wszechstronnie rozwinął się także kierowany wtedy przez Lubasia Instytut Filologii Polskiej, w którym ukształtowało się 11 zakładów, w tym 3 językoznawcze: Zakład Historii Języka Polskiego (od 1975 r.) kierowany przez Bajerową, Zakład Współczesnego Języka Polskiego (od 1975 r.) kierowany przez Wróbla oraz Zakład Dialektologii (od 1976 r.) kierowany przez Lubasia. Ważną rolę $w$ Instytucie odgrywał także Zakład Metodyki Nauczania Języka Polskiego i Literatury.

Oprócz dotychczasowych badań nad współczesną polszczyzną oraz historią języka wzmocniło się zainteresowanie językiem mieszkańców aglomeracji górnośląskiej. Zainspirowane przez Lubasia prace łączyły tradycyjne terenowe badania dialektologiczne z założe- 
niami rodzącej się wówczas socjolingwistyki. Opracowano teorię i metody opisu struktury języka, jakim $w$ życiu codziennym oraz $w$ regionalnych, lokalnych kontaktach posługują się zróżnicowani socjalnie, kulturowo i etnicznie mieszkańcy wielkich aglomeracji przemysłowych. Zbieraniem i opracowywaniem materiału zajmowali się badacze z Pracowni Polszczyzny Mówionej. Efektem tych działań są Teksty języka mówionego mieszkańców miast Górnego Śląska i Zagłębia (LuBAś, red., 1978-1980), liczne publikacje teoretyczne i opracowania monograficzne, a nade wszystko powołane w roku 1977 seryjne wydawnictwo ciągłe „Socjolingwistyka”, wydawane początkowo w ramach Prac Naukowych Uniwersytetu Śląskiego, później we współpracy z Instytutem Języka Polskiego PAN w Krakowie, a od roku 1990 (od numeru 9.) jako rocznik PAN (do dnia dzisiejszego).

Inauguracja roku akademickiego 1977/1978 zbiegła się z podziałem Instytutu Filologii Polskiej na dwie jednostki: Instytut Literatury i Kultury Polskiej oraz Instytut Języka Polskiego. Nowy Instytut o wyraźnie zaznaczonym profilu lingwistycznym tworzyły trzy wspomniane już zakłady językoznawcze oraz Zakład Metodyki Nauczania Języka Polskiego i Literatury. Problematyka badawcza Instytutu obejmowała: historię języka polskiego (w tym historię języka polskiego na Górnym Śląsku), generatywny opis czasowników polskich, słowotwórstwo współczesnego języka polskiego, socjolingwistykę, socjologię języka, język literatury pięknej. Badania nad ostatnim z wymienionych zagadnień rozwinęły się pod wpływem zatrudnionego w 1976 roku Aleksandra Wilkonia, który skupił wokół siebie grono studentów i młodych naukowców, zainteresowanych stylistyką lingwistyczną. Rezultaty dociekań w tym zakresie (analizy utworów literackich - współczesnych i dawnych, rozważania na gruncie onomastyki literackiej, rozprawy teoretyczne łączące literaturoznawcze metody opisu z oglądem językoznawczym) były publikowane w ukazującym się cyklicznie pod redakcją Wilkonia „Języku Artystycznym”, wydawanym - pod kierownictwem przedstawicieli kolejnych pokoleń językoznawczych - do dnia dzisiejszego. Nurt badań stylistycznych, ewoluujący później w kierunku lingwistyki tekstu i genologii lingwistycznej, zaowocował wieloma monografiami pracowników Instytutu Języka Polskiego.

W ciągu ponad czterdziestu lat istnienia Instytutu kierowało nim dziesięcioro dyrektorów, reprezentujących różne pokolenia i szkoły badawcze: Władysław Lubaś (1977-1981), Henryk Wróbel (1981-1983), Aleksander Wilkoń (1983-1989), Alina Kowalska (1989-1991), Krystyna Kleszczowa (1991-1993), Olga Wolińska (1993-2002), Małgorzata Kita (2002-2005), Jacek Warchala (2005-2012), Magdalena Pastuch (2012-2016), Mirosława Siuciak (2016-2019).

Rozwój badań językoznawczych oraz pojawienie się nowych metodologii i nurtów w nauce przyczyniły się do powstania zespołów badawczych, które z czasem przekształciły się $w$ nowe zakłady, utworzone obok tych już istniejących, czyli Zakładu Historii Języka Polskiego, kierowanego przez Alinę Kowalską, oraz Zakładu Współczesnego Języka Polskiego, kierowanego przez Ewę Jędrzejko. W 1993 roku z inicjatywy Krystyny Kleszczowej powstał Zakład Leksykologii i Semantyki, a rok później - Zakład Językoznawstwa Pragmatycznego, którego kierownictwo objęła Olga Wolińska. W roku 1995 z Instytutu wyodrębniła się kierowana przez Edwarda Polańskiego Katedra Dydaktyki Języka i Literatury Polskiej, która stała się odrębną jednostką Wydziału Filologicznego.

W działalności naukowej Instytutu cały czas daje się zauważyć kontynuacja nurtów zapoczątkowanych u zarania jego istnienia (przede wszystkim nurtu badań historycznojęzykowych), jak również tych dziedzin, które go konstytuowały w latach 70. i 80., a więc so- 
cjolingwistyki oraz szeroko rozumianych badań stylistycznych. W nawiązaniu do tej tradycji w roku 2011 powstał z inicjatywy Jacka Warchali Zakład Socjolingwistyki i Społecznych Praktyk Komunikowania oraz kierowany przez Bożenę Witosz Zakład Lingwistyki Tekstu i Dyskursu, w którym interpretuje się wybrane zjawiska zachodzące w różnych sferach współczesnej komunikacji z perspektywy badań nad dyskursem, genologii lingwistycznej, stylistyki, lingwistyki kulturowej i pragmatycznej.

Tematyka genologiczna jest $w$ Instytucie nieustannie obecna - dotyczy zjawisk nie tylko współczesnej kultury, ale także historii. Nurt genologiczny zakorzenił się bardzo mocno w Zakładzie Historii Języka Polskiego, szczególnie wówczas, gdy kierowała nim Danuta Ostaszewska. Zorganizowano cykl konferencji „Gatunki mowy i ich ewolucja”, które gromadziły wielu badaczy zainteresowanych funkcjonowaniem gatunków z perspektywy współczesnej oraz historycznej. Podjęto próby opisania rozwoju i przekształceń form gatunkowych $w$ ramach nowo wypracowanej metodologii, czego efektem jest kilka doktoratów oraz publikacji monograficznych. Obecnie problematyka ta ewoluuje $w$ kierunku powiązania gatunków z dyskursem oraz opisu zróżnicowania dyskursywnego dawnej przestrzeni komunikacyjnej.

Kilka lat temu oferta naukowa Instytutu została poszerzona o badania z zakresu logopedii. Organizowane są co roku międzynarodowe konferencje, których uczestnicy podejmują problemy z zakresu zaburzeń mowy. Publikowane są także liczne prace z tej dziedziny.

W roku 2014 powstało w Instytucie nowe pismo językoznawcze „Forum Lingwistyczne”, które prezentuje publikacje obejmujące szerokie spektrum mowy, a także przypomina $w$ każdym numerze dorobek wybitnych badaczy pracujących kiedyś lub obecnie $w$ Instytucie. W ciągu kilku lat czasopismo zyskało już znaczną renomę, czego przejawem jest coraz większa liczba nadsyłanych artykułów, także przez autorów zagranicznych.

Wyrazem hołdu dla Ireny Bajerowej - osoby, która miała bodaj największy wpływ na naukowy oraz osobowy rozwój Instytutu i związana z nim była prawie od początku, przez pół wieku przemieszczając się między Krakowem a Katowicami - było nadanie Instytutowi Języka Polskiego Jej imienia. Uroczystość ta miała miejsce podczas pierwszego Kongresu Historyków Języka w Katowicach, w kwietniu 2016 roku.

We wrześniu roku 2019 Instytut Języka Polskiego im. Ireny Bajerowej zakończył swoją działalność na skutek reorganizacji Uniwersytetu Śląskiego. Zmiana instytucjonalna nie wpłynie z pewnością na kształt i jakość podejmowanych badań, ponieważ katowickie środowisko lingwistyczne ma bardzo silne podstawy, ugruntowane przez ponad półwieczną tradycję. W językoznawstwie polonistycznym funkcjonuje nawet pojęcie śląskiej szkoły historycznojęzykowej, jak również stylistycznej i socjolingwistycznej, co świadczy o uznaniu dla kilku pokoleń badaczy, którzy te szkoły tworzyli. Na dorobek tego środowiska oprócz wielkiej liczby artykułów i książek naukowych składa się kilkadziesiąt kluczowych monografii, wyznaczających kierunki w badaniach językoznawczych i cytowanych do dzisiaj $w$ lingwistyce polskiej i światowej. Z perspektywy czasu wydaje się, że największym atutem opisywanego środowiska było zawsze łączenie solidnych podstaw badawczych z tym, co nowe $w$ lingwistyce, a obecność wielu wybitnych indywidualności językoznawczych nadała mu intelektualny rozmach i wszechstronność badawczą. 


\section{Literatura}

BAJERoWA I., 1964: Kształtowanie się systemu polskiego języka literackiego w XVIII wieku. Wrocław. LuBAŚ W., red., 1978-1980: Teksty języka mówionego mieszkańców miast Górnego Śląska i Zagłębia.

T. 1-2. Katowice.

PISAREK W., 1967: Poznać prasę po nagłówkach: nagłówek wypowiedzi prasowej w oświetleniu lingwistycznym. Kraków.

PolAńsKı K., red., 1980-1992: Słownik syntaktyczno-generatywny czasowników polskich. T. 1-4. Wrocław. T. 5. Kraków.

ZaręBA A., 1969-1989: Atlas językowy Śląska. T. 1-7. Warszawa.

ZAREB A A., red., 1961: Śląskie teksty gwarowe. Kraków.

Mirosława Siuciak

The History of the Irena Bajerowa Institute of the Polish Language

Summary

The tert is a brief description of the history of the Irena Bajerowa Institute of the Polish Language that existed between 1977 and 2019. The beginnings of linguistics in Katowice date back to the 1960s and were connected with the research activity of the most prominent representatives of linguistics in Poland (Witold Mańczak, Maria Honowska, Irena Bajerowa, Kazimierz Polański, Walery Pisarek) who had been educated at the Jagiellonian University. The research work of the Department of the Polish Language, which existed back then, concentrated mainly on diachronic issues and the problems of contemporary word formation and syntax.

The foundation of the University of Silesia in 1968 expedited the academic development of the aforementioned linguistic society, which contributed to a philological community of a great potential. In the 70s, the Faculty of Philology was created, whereas the Institute of the Polish Language was established in its structure. This institution gathered many outstanding researchers, often including the precursors of new trends in the Polish academia, such as generative grammar, sociolinguistics, linguistic stylistics. Numerous groundbreaking studies and journals, Socjolingwistyka and Język Artystyczny, were published there as well.

The activity of the remarkable linguists and their students contributed to the formation of the research approaches well-known in Poland and abroad, including historical linguistics, sociolinguistics, and stylistics. In 2016, the Institute of the Polish Language was given the name of Irena Bajerowa, that is, the researcher who was closely connected with Silesian linguistic community, who inspired this community to think comprehensively about language and linguistics, and who took care of its academic development. 